\title{
To the problem of influence of storage conditions on quality of medicinal plant raw materials
}

Kutsyk T. ${ }^{1}$, Gorlachova I. ${ }^{2}$, Hlushchenko L.. ${ }^{3}$

Experimental station of drug plants of Institute agroecology and natural management of NAAS, Pokrovska Str., 16a, Berezotocha, Lubenskyi region, Poltava oblast, 37535, Ukraine; e-mail: ${ }^{1}$ tkucyk1978@ukr.net, ${ }^{2,3}$ ukrvilar@ukr.net

The purpose. To study influence of some factors on quality of plant raw materials at storage. Methods. Generalization of results of researches by laboratory, analytical, mathematical-statistical, and calculationcomparative methods. Results. Optimum storage conditions of 4 kinds of medicinal plant raw materials (Flores Calendulae, Flores Chamomillae, Radix Scutellariae baicalensis, Herba Althaeae) which ensure long saving quality of product are specified. Conclusions. Standardization is one of the major mechanisms for security and quality control of medicinal plant raw materials. Different biologically active agents in raw material require individual approach to determination of optimum conditions and methods of their storage, as well as development of normative deeds which would regulate conditions of preserving quality of raw material, and terms of their validity.

Key words: medicinal plant raw materials, methods of storage, quality, standardization.

\section{https://doi.org/10.31073/agrovisnyk201806-10}

The introduction into the domestic medical practice of new types of medicinal plant material, products of its processing, expansion of the range of medicines based on medicinal plants, requires the improvement of the standardization system and control of their quality. Medicinal products, including medicinal plant materials used in medical practice, must meet all current safety requirements and be effective in the treatment of human diseases.

As the world experience shows, it is much more effective to ensure quality control at all stages of the development of medicines from medicinal plants than to carry it out after the preparation was been made. It allows will unify normative documents, reduce the cost and time in the manufacture of medicines and improve their quality. For the vast majority of medicinal plant material, quality is set according to standard content of biologically active ingredients that provide therapeutic efficacy of drugs. While for specific types of raw materials, whose active components are not yet established, or those in which the complex of substances is active, specific marker substances for quality control may be selected [1,2].

Thus, the quality assurance chain should cover the whole cycle of the drug from the raw material to the medicines based on medicinal plants and regulate each stage of production by an appropriate document that guarantees the quality of the final product.

Each country has its own set of guidelines for assessing and controlling the quality of medicines based on medicinal plants. The importance of quality control and standardization of medicinal plant material for their production is a matter of concern regarding the global acceptability of these parameters in modern pharmacy and medicine. Such an assessment is required at various stages of the production of medicinal plant material and subsequent stages of post-production [3].

In our country, work is constantly being was carried out on the approximation of domestic quality standards having national differences to the standards adopted in international practice. Since Ukraine is currently in the stage of implementation and harmonization of the regulatory framework of the pharmaceutical sector with European and international legislation, as well as the implementation of its principles in the activities of pharmaceutical companies, standardization and quality control at all stages of the production of medicinal plant material is extremely relevant [4].

Legal relations regarding the creation, registration, production, quality control and sale of medicinal plant material and its products are regulated by the Law of Ukraine "On Medicines". The Ministry of Health of Ukraine 
carries out management in the field of creation, production, quality control and sale of medicinal plant raw materials. The system of ensuring and guaranteeing the quality of raw materials for the production of medicines based on medicinal plants in Ukraine includes:

- System of registration and licensing of medicinal products of plant origin.

- Quality control system.

- A system of principles and rules of good manufacturing practice (GMP).

- System of Good Practice for Cultivation and Collection of Medicinal Plants (GACP) [5].

At present, the main documents defining the authenticity, purity and quality of medicinal plant material are: State Pharmacopoeia of Ukraine (DFU), separate pharmacopoeia articles (FS), pharmacopoeia articles of the enterprise (FAS), state standard (DSTU), industry standards (GST ), enterprise standards (STIs), technical specifications (TU) and technological instructions ( $\mathrm{TI})$. The requirements for medicinal plant material specified in the documents are obligatory for all enterprises and institutions of Ukraine, which manufacture, preserve, control and apply medicinal raw materials $[4,5]$.

In particular, in Ukraine the current State Pharmacopoeia, harmonized with the European Pharmacopoeia, includes 173 monographs on medicinal plant material with quality control in accordance with the requirements of the European Union [6]. Order of the Ministry of Health № 118 dated February 14, 2013 approved the Regulation of the ST-N MOHU 42.4.5: 2012 "Medicines. Good practices for cultivating and harvesting raw materials of plant origin [7].

According to the indicated normative documents, the preparation of medicinal plant material provides a list of standard procedures that are necessary to ensure the availability of quality pharmaceutical products. In particular, the storage and processing of medicinal plant material are important preparatory stages due to the multicomponent composition of medicinal plants and the variable nature of this composition under different storage and processing conditions.

Storage - a process that ensures the quality of the raw material during its shelf life, Factors influencing the expiration date are the chemical composition of medicinal plant material, degree of shredding, etc.

Expiration date are individual for each type of raw material and establishes experimentally. However, storage conditions, in particular in warehouse space - temperature regime, humidity, illumination, packaging materials, can significantly affect the shelf life and quality of raw materials.

To obtain high-quality pharmaceutical products, it is necessary to develop regulatory documents that include all measures to preserve high-quality medicinal plant material. It is especially important to adhere to such rules when cultivating new types of medicinal plants, where all stages of production are in the process of development.

Out in this area is constantly research carrier at the Experimental Station of Medicinal Plants at the Institute of Agroecology of Nature Management of the National Academy of Sciences of Ukraine.

We conducted preliminary studies to determine the peculiarities of storing certain types of raw materials under different conditions and the physical state of raw materials using classical methodological approaches [8].

Goal. To study the influence of individual factors on the quality of medicinal plant material during storage.

Materials and methods of research. The objects of the research were Flores Calendulae, Flores Chamomillae, Radix Scutellariae baicalensis, Herba Althaeae.

Storage of whole (not crushed) raw materials was carried out under the temperature regime within $(0 \div+5)$ ${ }^{\circ} \mathrm{C}$ with natural light (№1). The temperature regime - $(+5 \div+10){ }^{\circ} \mathrm{C}$ without light access (№2) - the windows of the room were closed with a hard paper. Control (№ 3) served the storage of raw materials for the temperature regime $-(+10 \div+20){ }^{\circ} \mathrm{C}$ without direct exposure to sunlight. The raw materials of the experimental variants were pack in polypropylene bags, control - paper multilayer bags.

Tests of medicinal plant material were conduct in accordance with the methods indicated in the State Pharmacopoeia of Ukraine (Pharmacopoeia of Ukraine) and the Pharmacopoeia article for the Radix Scutellariae baicalensis.

Statistical processing of the results was perform using Microsoft Office 2003, Excel 6.1 / prof and Statistica licensed software. 
Research results. Storage is a process that ensures the quality of the raw material during the established shelf life. For shelf life, factors such as chemical composition, degree of shredding, storage conditions are affected.

Expiration date are individual for each type of raw material and establishes experimentally. However, storage conditions, in particular in warehouses - temperature regime, humidity, illumination, packaging materials can significantly affect the shelf life and quality of raw materials.

In order to have a communication between the quality of raw materials, regulatory requirements and the quality of the final product, it is necessary to develop appropriate rules based on the description of all measures that ensure, during the production process, the reproducibility of qualitative characteristics. These approaches are especially important when cultivating new types of medicinal plants, where all stages of production, from cultivation to replenishment and storage, are only being developed or improved. Researches in this area are constantly carry out at the Experimental Station of Medicinal Plants IAP NAAS.

We conducted preliminary studies to determine the peculiarities of storing certain types of raw materials under different conditions and the physical state of raw materials using classical methodological approaches [9].

Until the beginning of the research work, the premises of the warehouse and shelving for the storage of raw materials were, disinfect. The raw material was stored in dry, clean, well-ventilated spacious rooms equipped with devices for monitoring temperature and humidity. Humidity was maintain at the level $(45-60) \%$, the temperature regime and lighting were adjust according to the experimental scheme.

The raw materials were place on shelves. Shelves were install at a distance of not less than $25 \mathrm{~cm}$ from the floor and not less than $60 \mathrm{~cm}$ from the wall. The stacking height in the stack is no more than $4 \mathrm{~m}$. The distance between the racks were lift up to $2 \mathrm{~m}$. Each stack was equipped with a label indicating the name of the raw material, the name of the manufacturer, the year and month of the processes, the batch number, the date of receipt, and other indicators that may affect terms of preservation of qualitative characteristics of raw materials.

1. Characteristics of medicinal plant material at the end of the experiment when stored for $\mathbf{1 2}$ months.

\begin{tabular}{|c|c|c|c|c|c|c|c|}
\hline \multirow{3}{*}{$\begin{array}{l}\mathrm{N} \\
\mathrm{o} \\
\mathrm{n} \\
/ \\
\mathrm{n}\end{array}$} & \multirow{3}{*}{$\begin{array}{l}\text { Name of raw } \\
\text { material }\end{array}$} & \multicolumn{6}{|c|}{ Characteristics: } \\
\hline & & \multicolumn{3}{|c|}{ Mass fraction of moisture, $\%$} & \multicolumn{3}{|c|}{ Content of active substances, $\%$} \\
\hline & & №1 & №2 & №3 & №1 & №2 & №3 \\
\hline \multirow[t]{3}{*}{1} & \multirow{3}{*}{$\begin{array}{l}\text { Flowers of } \\
\text { medicinal } \\
\text { marigolds } \\
\text { (Flores } \\
\text { Calendulae) }\end{array}$} & $14,5 \pm 0,2$ & $11,4 \pm 0,3$ & $11,3 \pm 0,2$ & \multicolumn{3}{|c|}{ The sum of flavonoids } \\
\hline & & \multirow{2}{*}{\multicolumn{3}{|c|}{ Norm 14,0 [6] }} & $0,48 \pm 0,03$ & $0,56 \pm 0,03$ & $0,50 \pm 0,03$ \\
\hline & & & & & \multicolumn{3}{|c|}{ Norm 0,40 [6] } \\
\hline \multirow[t]{3}{*}{2.} & \multirow{3}{*}{$\begin{array}{l}\text { Flowers of } \\
\text { chamomile } \\
\text { medical } \\
\text { (Flores } \\
\text { Chamomillae) }\end{array}$} & $13,1 \pm 0,1$ & $10,8 \pm 0,1$ & $10,5 \pm 0,1$ & \multicolumn{3}{|c|}{ Essential oils } \\
\hline & & \multirow{2}{*}{\multicolumn{3}{|c|}{ Norm 12,0 [6] }} & $0,40 \pm 0,01$ & $0,55 \pm 0,01$ & $0,48 \pm 0,01$ \\
\hline & & & & & \multicolumn{3}{|c|}{ Norm0,3[6] } \\
\hline \multirow[t]{3}{*}{3.} & \multirow{3}{*}{$\begin{array}{l}\text { Roots } \\
\text { Baikal (Radix } \\
\text { Scutellariae } \\
\text { baicalensis) }\end{array}$} & $10,0 \pm 0,3$ & $9,7 \pm 0,1$ & $9,7 \pm 0,3$ & \multicolumn{3}{|c|}{ The sum of glycosides } \\
\hline & & \multirow{2}{*}{\multicolumn{3}{|c|}{ Norm 10,0 [10] }} & $19,2 \pm 0,3$ & $19,1 \pm 0,3$ & $18,2 \pm 0,3$ \\
\hline & & & & & \multicolumn{3}{|c|}{ Norm 15,0 [10] } \\
\hline \multirow[t]{3}{*}{4.} & \multirow{3}{*}{$\begin{array}{l}\text { Herb Althaeae } \\
\text { (Herba Althaeae) }\end{array}$} & $14,5 \pm 0,1$ & $11,8 \pm 0,3$ & $11,5 \pm 0,2$ & \multicolumn{3}{|c|}{ Polysaccharides } \\
\hline & & \multirow{2}{*}{\multicolumn{3}{|c|}{ Norm 13,0 [6] }} & $6,5 \pm 0,05$ & $6,3 \pm 0,05$ & $6,0 \pm 0,05$ \\
\hline & & & & & \multicolumn{3}{|c|}{ Norm 5,0 [6] } \\
\hline
\end{tabular}


The raw material were periodically inspected for the presence pests and the compliance with the shelf life and selected samples to control the quality of raw materials and determine the dynamics of loss of quality characteristics specified in the normative documentation for specific types of raw materials.

As the researches showed, packaging made of polypropylene were can be used for long-term storage of medicinal plant material. The content of biologically active substances in the raw material, which was stored in polypropylene and paper bags, did not differ in different lighting and temperature conditions and fully met normative requirements according (Table 1 and 2 ).

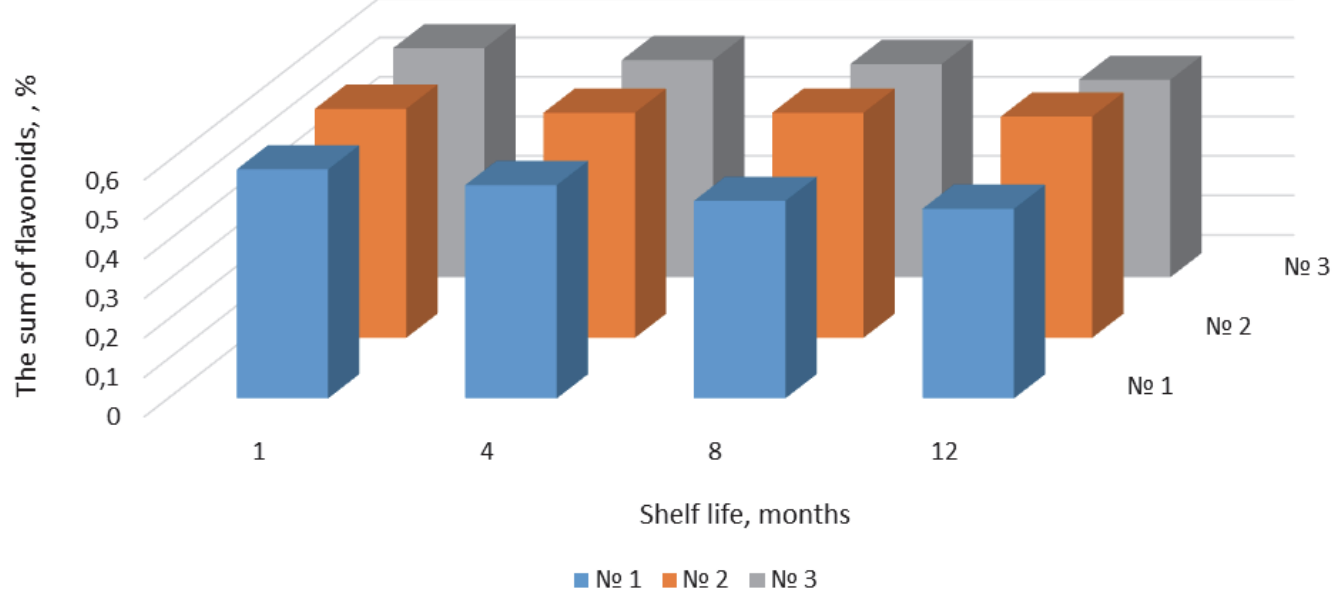

Fig.1. Dynamics of the content of the amount of flavonoids in the flowers of medicinal marigolds.

The most influential was the temperature regime and lighting features. At temperature conditions $(10-20)^{\circ} \mathrm{C}$ quality indices of raw materials were somewhat higher than for storage in a cold room: the darkening of raw materials was not observe, but the content of essential oils decreased by an average of (14-15) \%.

When stored at low temperatures of the Flores Calendulae lost the intensity of the colour, and in the room with a temperature regime (10-20) ${ }^{\circ} \mathrm{C}$ and without the access of light, the colour kept the brightness and intensity. The content of flavonoids in the year of storage fully met the regulatory requirements and was within $(0.67-1.1 \%)$ for different samples of Flores Calendulae, the temperature regime and lighting did not affect this indicator (Figure 1).

Flores Chamomillae for the year of storage in conditions of reduced temperature have undergone slight changes - some darkening, an increase in the amount of oscillation up to $20 \%$, the content of essential oils has undergone a slight decrease, the amount mineral and organic impurities did not change (Table 2 and Figure 2).

2. Organoleptic assessment of the quality of medicinal plant material in different conditions of storage for 12 months.

\begin{tabular}{|c|c|c|c|c|}
\hline \multirow[t]{3}{*}{ Option } & \multicolumn{4}{|c|}{ Features: } \\
\hline & \multicolumn{2}{|c|}{ Organoleptic evaluation: } & \multicolumn{2}{|c|}{ Side impurities, $\%$} \\
\hline & colour & Scent / taste & organic & mineral \\
\hline 1. & \multicolumn{4}{|c|}{ Flores Calendulae } \\
\hline №1 & $\begin{array}{l}\text { from bright orange to pale- } \\
\text { orange }\end{array}$ & saturated & $1,00 \div 0,50$ & 0,00 \\
\hline №2 & from bright orange to orange & saturated & $0,50 \div 0,20$ & 0,00 \\
\hline №3 & $\begin{array}{l}\text { from bright orange to orange } \\
\text { [6] }\end{array}$ & saturated [6] & $0,50[6]$ & $0,50[6]$ \\
\hline 2. & \multicolumn{4}{|c|}{ Flores Chamomillae } \\
\hline № 1 & partially darkened strong, & $\begin{array}{l}\text { strong, fragrant with the smell of } \\
\text { mould/ spicy, bitter, slightly } \\
\text { mucous }\end{array}$ & $1,53 \div 1,50$ & $\begin{array}{l}1,00 \div \\
0,00\end{array}$ \\
\hline
\end{tabular}




\begin{tabular}{|c|c|c|c|c|}
\hline № 2 & light & $\begin{array}{l}\text { intense aromatic, specific / } \\
\text { without changes spicy, bitter, } \\
\text { slightly mucous }\end{array}$ & $1,55 \div 1,30$ & $\begin{array}{l}1,00 \div \\
0,00\end{array}$ \\
\hline № 3 & light [6] & $\begin{array}{l}\text { strong aromatic, specific / spicy, } \\
\text { bitter, slightly mucous [6] }\end{array}$ & $3,00[6]$ & $0,50[6]$ \\
\hline 3. & \multicolumn{4}{|c|}{ Radix Scutellariae baicalensis } \\
\hline №1 & $\begin{array}{l}\text { is inherent in this type of raw } \\
\text { material, the individual ones } \\
\text { are darker }\end{array}$ & specific /bitter & 0,00 & 0,00 \\
\hline № 2 & $\begin{array}{l}\text { is specific to this type of raw } \\
\text { material }\end{array}$ & specific / bitter & 0,00 & 0,00 \\
\hline № 3 & $\begin{array}{l}\text { is inherent in this type of raw } \\
\text { material [9] }\end{array}$ & specific / bitter [9] & $0,5[9]$ & $0,5[9]$ \\
\hline 4. & \multicolumn{4}{|c|}{ Herba Althaeae } \\
\hline № 1 & grey - green & $\begin{array}{l}\text { weak, specific vegetative / } \\
\text { slightly mucous }\end{array}$ & $0,11 \div 0,00$ & 0,00 \\
\hline № 2 & grey - green & $\begin{array}{l}\text { weak, specific vegetative / } \\
\text { slightly mucous }\end{array}$ & $0,10 \div 0,00$ & 0,00 \\
\hline № 3 & grey - green [6] & $\begin{array}{l}\text { weak, specific vegetative / } \\
\text { slightly mucous [6] }\end{array}$ & $3,0[6]$ & $1,5[6]$ \\
\hline
\end{tabular}

The raw material of the Radix Scutellariae baicalensis has changed the coloration - the marked darkening of individual roots after 6 months of storage in a cold room, the number of roots that changed the colour after 12 months of storage was about $10 \%$. The content of active substances varied depending on storage conditions. The best option was the one where the raw material was stored at reduced temperatures. According to other external indicators, such as mineral and organic impurities, changes within the permissible norm (Table 1, 2 and Fig. 3).

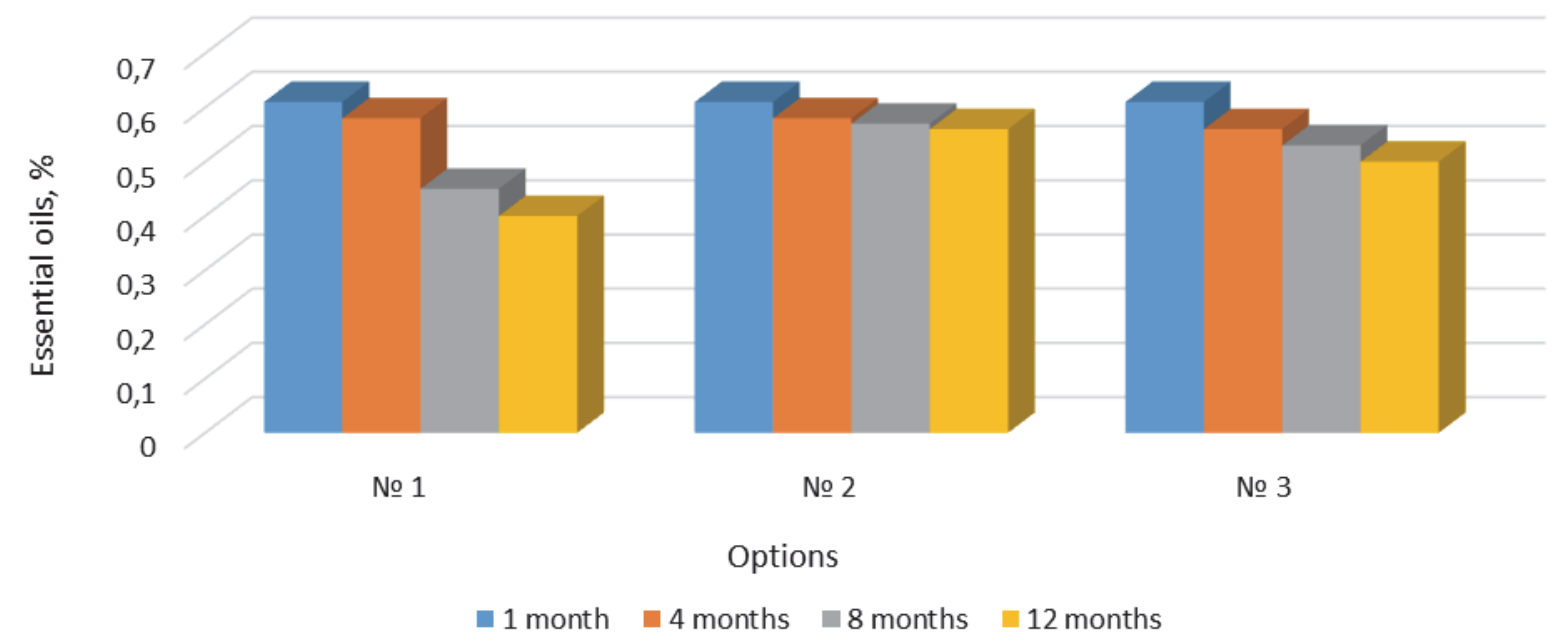

Fig.2. Changing the amount of essential oil in chamomile medicinal flowers when stored (12 months). 


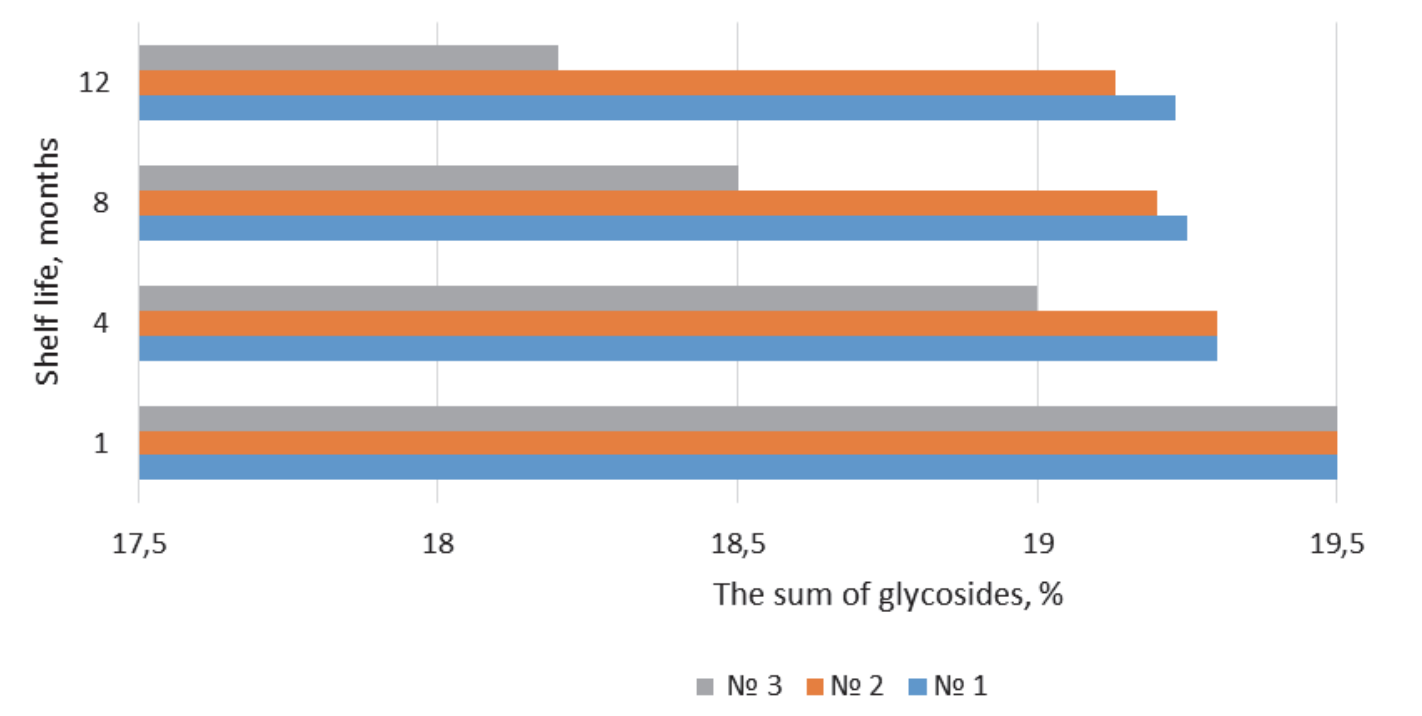

Fig. 3. Content of the sum of glycosides in Radix Scutellariae baicalensis during storage.

The storage and lighting temperature of the premises had a slight effect on the quality of the Herba Althaeae. The number of polysaccharides, albeit subject to change, remained within the regulatory requirements throughout the storage period (Table 1, 2 and Fig. 4).

In studies, lighting and storage temperature vary widely on the quality of medicinal plant material. The optimum storage conditions of four types of medicinal plant material - Flores Calendulae, Flores Chamomillae and Radix Scutellariae baicalensis, Hebra Althaeae, which provide long-term preservation of product quality, are determined. In particular, the raw materials Flores Calendulae must be stored without lighting at $10-20^{\circ} \mathrm{C}$.

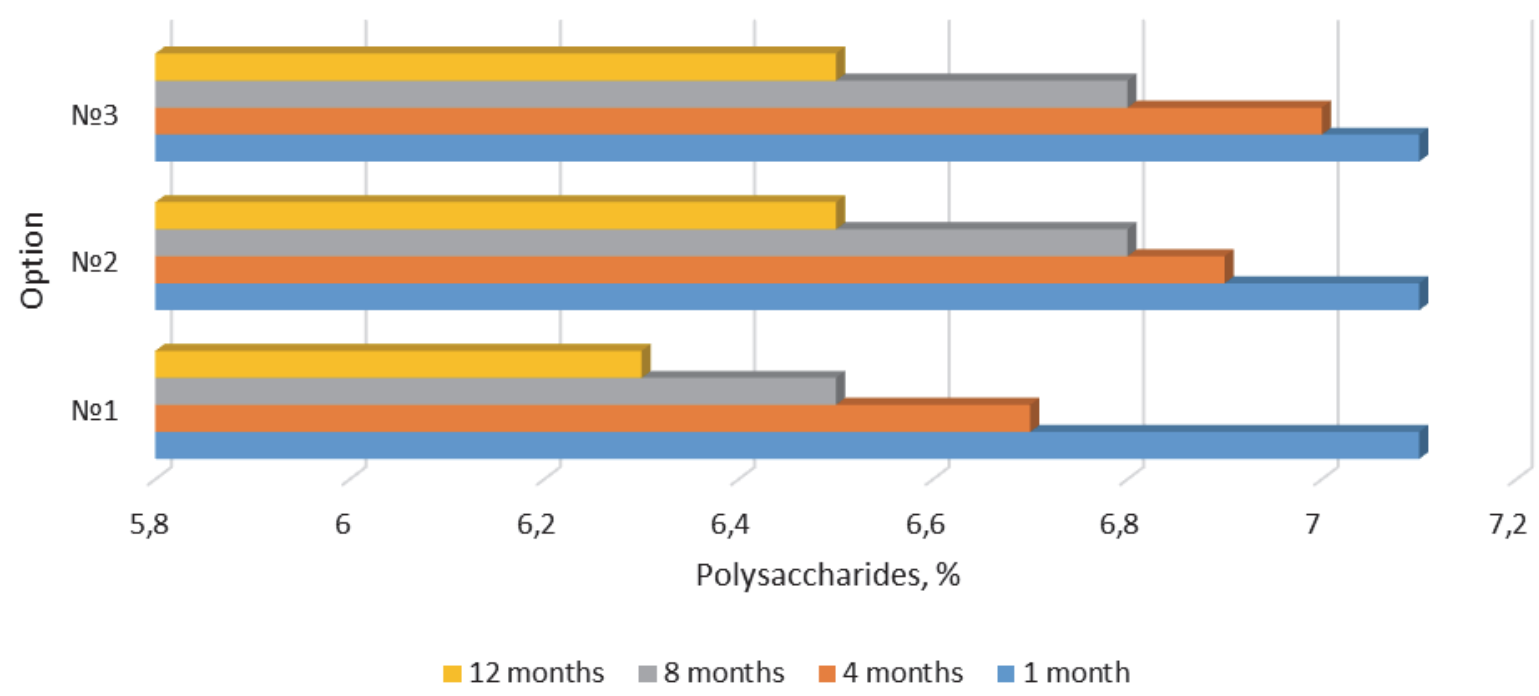

Fig. 4. Content of the amount of polysaccharides in the medicinal grass grass when stored

In addition, the results of research at temperature $(+5 \div 10){ }^{\circ} \mathrm{C}$ without light access (№2), where the indicators are not lower than the control ones, while saving the heat in the warehouses, are noteworthy.

Flores Chamomillae for prolonged preservation of the essential oil content should be kept at a reduced temperature, but it can be inferior to external indicators.

The result of establishing optimal conditions for preserving the quality of medicinal plant material is to reduce its cost and to use effectively both cultivated and wild herbs. 


\section{Conclusions.}

The optimum conditions of storage of four types of medicinal plant material, which ensure the long-term preservation of its quality, are determined: Flores Calendulae, Flores Chamomillae, Radix Scutellariae baicalensis, Herba Althaeae. The result of establishing optimal conditions for the preservation of the quality of medicinal plant material is to reduce its value and to use the products effectively, both medicinal plant growing and wild species of medicinal plants. The main task for further research is to study and standardize the processes of storing the largest amount of medicinal plant material, their proper description, characterization and inclusion in official standards and regulations for the unification of all processes.

\section{Bibliography}

1. Dixit V.K., Yadav N.P. (2008). Recent approaches in herbal drug standardization. Integr. Biol. 2(3). P. $195-203$.

2. Nikam P., Kareparamban J., Jadhan A., Kadam V. (2012). Future trends in standardization of herbal drugs. J. of Applied Pharmaceutical Science.. 2(6). P. $38-44$.

3. Ahmad I., Ahmad Khan M.S., Cameotra S.S. (2014). Quality Assessment of Herbal Drugs and Medicinal Plant Products. Encyclopedia of Analytical Che-mistry. P. 1 - 17.

4. Veliutneva V.O., Ubohov S.H., Budnikova T.M. et al. (2013). Normatyvno-pravove rehuliuvannia u sferi zabezpechennia yakosti likarskykh zasobiv $v$ Ukraini: retrospektyvnyi analiz. [Regulatory and Legal Regulation in the Field of Quality Assurance in Medicines in Ukraine: A Retrospective Analysis]. Farmatsevtychnyi zhurnal. № 4. P. 9-18. [in Ukrainian].

5. Zelysko D.S., Kravchuk Zh.N. Zelisko D.S., Kravchuk Zh.N. (2016). Sovremennye trebovaniya k kachestvu i standartizacii lekarstvennogo rastitelnogo syrya. [Modern requirements to the quality and standardization of medicinal plant raw materials]. Ahroekolohichnyi zhurnal. № 2. P. 49 - 59. [in Russian].

6. Derzhavna farmakopeia Ukrainy. (2014). [State Pharmacopoeia of Ukraine]. Kharkiv: DP «Ukrainskyi naukovyi farmakopeinyi tsentr yakosti likarskykh zasobiv»,.T. 3. 732 p. [in Ukrainian].

7. Nastanova. Likarski zasoby. Nalezhna praktyka kultyvuvannia ta zbyrannia vykhidnoi syrovyny roslynnoho pokhodzhennia: ST-N MOZU 42-4.5:2012. [Attitude. Medicines. Good practice in cultivating and harvesting raw materials of plant origin ST-N MOZU 42-4.5:2012]. (2012). Kyiv: Ministerstvo okhorony zdorovia Ukrainy, 13 p. [in Ukrainian].

8. Kolektyv avtoriv. (2016). Nalezhna praktyka kultyvuvannia i zboru likarskoi roslynnoi syrovyny (GACP) yak harantiia yakosti likarskoi roslynnoi syrovyny i preparativ na yii osnovi. Naukovo-praktychnyi posibnyk. [Good practices for the cultivation and collection of medicinal plant material (GACP) as a guarantee of quality of medicinal plant material and preparations on its basis]. Lubny: Komunalne vydavnytstvo «Lubny». 100 p. [in Ukrainian].

9. Kovalov V.M., Pavlii O.I., Isakova T.I. (2004). Farmakohnoziia z osnovamy biokhimii roslyn: pidr. dlia stud. vyshch. farmats. navch. zakl. ta farmats. f-tiv vyshchykh med. navch. zakl. III - IV rivniv akred. (2-e vyd.). [Pharmacognosy with the basics of biochemistry of plants: a textbook for students of higher pharmaceutical schools and pharmaceutical faculties of higher medical educational institutions of the III-IV levels of accreditation (2 editions)]. Kharkiv: vyd-vo NfaU, MTK-knyha. 704 c. [in Ukrainian].

10. VFS U42-1-92. Kornevisha i korni shlemnika bajkalskogo kultiviruemogo. [VFS U42-1-92. Kornevisha i korni shlemnika bajkalskogo kultiviruemogo]. 1995. 12 p. [in Russian].

1. 